\title{
PENGEMBANGAN MODUL KOMPUTER AKUNTANSI DENGAN PENDEKATAN BUKTI TRANSAKSI
}

\author{
Moh. Nurslamet Fauzi \\ Staf Pajak PT. Pancanaka \\ fauzi_um@ymail.com
}

\begin{abstract}
At vocational high school (SMK), the students are directed more at expertise competencies that can be applied at work. One of them is computerized accounting. Based on the preliminary study in the learning process of computerized accounting lesson at Class XII Accounting of SMK Widya Dharma Turen, a fact is obtained that the usage of module can't overcome the learning difficulties of the students due to the lack of explanation in the module regarding the steps of operating the computerized accounting program. The module only contains questions that done by students with computerized accounting program. Therefore, the author intends to develop a module of computerized accounting with evidence of transaction approach. This approach is used to solve the issue, approach the real accounting activity, and suit the needs of vocational students to be prepared for work.

The development model used here is the Borg and Gall's model. The steps include the analysis of needs assessment, module development, feasibility test, first revision, restricted test, second revision, and final product. The module feasibility test is conducted by two experts, the material expert and the development of teaching material expert, to overview the quality of the module. Meanwhile, the restricted test is conducted to find the weakness of the product from the students' point of view.

Based on the feasibility test, the material expert and the development of teaching material expert state that the module is valid to use with the percentage of $97,45 \%$ and $100 \%$. After the first revision based on the comments and suggestions from the validator, the module is tested on the students as users. Based on the restricted test, the module is valid with the percentage of $89,51 \%$. Furthermore, it results the final product after the second revision based on the comments and suggestions from the users.

The advantage of the product is a module that uses the evidence of transaction and practical approach, so it is easier for students to understand and apply. On the other hand, the product still has some shortcomings. Not all kinds of evidence of transaction are used in the module and the effectiveness in leaning has not been proven. Moreover, the number of validators are limited by two experts. Therefore, the author suggests for further product development, which include the addition of evidence of transaction in the module, effectiveness test in learning activities, and the addition of validators to increase the objectivity.
\end{abstract}

Keywords: module, computerized accounting, evidence of transaction approach

\footnotetext{
Abstrak: Pada Sekolah Menengah Kejuruan (SMK), siswa lebih diarahkan pada kompetensi keahlian yang dapat diterapkan secara langsung dalam dunia kerja. Salah satunya adalah dengan adanya mata pelajaran komputer akuntansi.Berdasarkan studi awal yang dilakukan oleh peneliti pada proses pembelajaran komputer akuntansi di kelas XII Akuntansi SMK Widya Dharma Turen, diperoleh fakta bahwa penggunaan modul pembelajaran belum mampu mengatasi
} 
kesulitan belajar siswa. Hal tersebut disebabkan oleh tidak adanya penjelasan materi dalam modul tentang langkah-langkah dalam mengoperasikan program komputer akuntansi. Modul hanya berisi soal-soal yang dikerjakan oleh siswa dengan program komputer akuntansi. Oleh karena itu, peneliti bermaksud untuk mengembangkan modul komputer akuntansi dengan pendekatan bukti transaksi. Pendekatan ini dipilih sebagai upaya untuk mengatasi masalah tersebut serta agar modul ini mendekati kegiatan akuntansi secara nyata.Hal tersebut dimaksudkan untuk menyesuaikan dengan kebutuhan kompetensi lulusan siswa SMK yang dipersiapkan untuk siap terjun ke dunia kerja.

Model pengembangan yang digunakan yaitu model Borg dan Gall. Adapun langkahlangkah yang dilakukan meliputi analisis kebutuhan, pengembangan modul, uji kelayakan modul, revisi pertama, uji coba pengguna terbatas, revisi kedua, serta produk akhir. Uji kelayakan modul dilakukan oleh dua ahli, yaitu ahli materi dan ahli pengembangan bahan ajar, untuk melihat kualitas modul yang dihasilkan. Sedangkan uji coba pengguna terbatas dilakukan untuk melihat kelemahan-kelemahan yang ada dalam produk dilihat dari sudut pandang siswa.

Berdasarkan uji kelayakan modul, ahli materi dan ahli pengembangan bahan ajar menyatakan bahwa modul telah valid untuk digunakan dengan persentase masing-masing $97,45 \%$ dan $100 \%$. Setelah dilakukan revisi pertama berdasarkan kritik dan saran dari validator, kemudian modul diujicobakan pada siswa sebagai pengguna. Berdasarkan uji coba pengguna terbatas, modul dinyatakan valid dan layak digunakan dengan presentase $89,51 \%$. Selanjutnya, dihasilkan produk akhir setelah dilakukan revisi kedua pada modul berdasarkan kritik dan saran dari pengguna.

Keunggulan dari produk yang dikembangkan adalah penyusunan modul yang menggunakan pendekatan bukti transaksi dan pendekatan praktik, sehingga materi tersebut lebih mudah untuk dipahami dan dipraktikan oleh siswa.Namun di sisi lain, produk tersebut memiliki beberapa kekurangan, yaitu belum digunakannya semua jenis bukti transaksi di dalam modul, belum terujinya efektivitas modul dalam pembelajaran, serta terbatasnya validator yang hanya terdiri dari dua orang ahli. Oleh karena itu, saran peneliti untuk pengembangan produk lebih lanjut adalah penambahan jenis bukti transaksi di dalam modul, dilakukannya uji efektivitas modul dalam kegiatan pembelajaran, serta penambahan validator untuk meningkatkan objektivitas penilaian pada modul.

Kata Kunci: modul, komputer akuntansi, pendekatan bukti transaksi

Pendidikan memegang peranan yang sangat penting bagi kemajuan suatu bangsa. Melalui pendidikan, generasi penerus bangsa akan dipersiapkan dengan baik. Pendidikan yang bermutu merupakan pendidikan yang di dalamnya terjadi proses pembelajaran yang efektif. Pembelajaran yang efektif ditandai dengan suasana belajar yang menyenangkan, penggunaan media pembelajaran yang sesuai, penggunaan metode yang bervariasi, serta adanya interaksi belajar yang kondusif.

Salah satu cara untuk mencapai pembelajaran yang efektif adalah dengan penggunaan modul pembelajaran. Nasution (2010: 205) mendefinisikan modul sebagai suatu unit yang lengkap yang berdiri sendiri dan terdiri atas suatu rangkaian kegiatan belajar yang disusun untuk membantu siswa mencapai sejumlah tujuan yang 
dirumuskan secara khusus dan jelas. Modul yang disusun dengan baik dapat memberikan banyak keuntungan, baik bagi siswa maupun pengajar.

Penggunaan modul dalam pembelajaran dapat meningkatkan motivasi belajar siswa. Pengajaran dengan modul akan membuka kesempatan bagi siswa untuk belajar menurut kecepatan masing-masing. Dengan demikian, siswa akan lebih aktif untuk belajar secara mandiri. Di sisi lain, pembelajaran dengan mengunakan modul akan memberikan kesempatan yang lebih besar dan waktu yang lebih banyak kepada guru untuk memberikan bantuan dan perhatian individual kepada setiap siswa yang membutuhkan, tanpa mengganggu atau melibatkan seluruh kelas. Dengan kata lain, peran guru tidak lagi sebagai sumber belajar, namun sebagai fasilitator pembelajaran.

Pada Sekolah Menengah Kejuruan (SMK), siswa lebih diarahkan pada kompetensi keahlian yang dapat diterapkan secara langsung dalam dunia kerja. Salah satunya adalah dengan adanya Mata Pelajaran Komputer Akuntansi. Komputer Akuntansi merupakan mata pelajaran yang termasuk kelompok program produktif dalam program keahlian akuntansi. Selain pemahaman yang harus dikuasai, siswa juga harus memiliki sikap dan kemampuan praktik dalam mengerjakan siklus akuntansi menggunakan komputer sesuai dengan prosedur dan standar kompetensi yang diharapkan. Hal tersebut dimaksudkan agar kompetensi lulusan dari siswa Sekolah Menengah Kejuruan (SMK), khususnya pada program keahlian akuntansi mampu bersaing dalam dunia kerja.

Berdasarkan studi awal yang dilakukan oleh peneliti pada proses pembelajaran komputer akuntansi, permasalahan yang terjadi adalah siswa kurang memiliki keterampilan dalam pengoperasian program komputer akuntansi. Meskipun telah ada modul yang digunakan dalam proses pembelajaran, namun masih belum dapat mengatasi permasalahan tersebut. Hal demikian disebabkan oleh tidak adanya penjelasan langkah-langkah dalam mengoperasikan program komputer akuntansi dalam modul. Modul hanya berisi soal-soal yang dikerjakan dengan program komputer akuntansi. Sehingga siswa mengalami kesulitan dalam mengoperasikan program komputer akuntansi.

Selain kurangnya keterampilan dalam pengoperasian program komputer akuntansi, siswa di SMK Widya Dharma Turen juga masih kurang menguasai teknik analisis bukti transaksi yang akan dibukukan ke dalam siklus akuntansi. Bahkan 
sebagian siswa ada yang mengalami kesulitan dalam membedakan macam-macam bukti transaksi. Hal demikian disebabkan oleh penyajian materi dan soal-soal dalam modul komputer akuntansi yang saat ini digunakan masih menggunakan soal dalam bentuk cerita.

Dengan demikian, pengembangan Modul Komputer Akuntansi dengan Pendekatan Bukti Transaksi merupakan upaya yang tepat untuk mengatasi permasalahan tersebut. Pendekatan ini dipilih sebagai upaya agar modul ini mendekati kegiatan akuntansi secara nyata. Selain itu, dengan menggunakan pendekatan ini siswa dapat lebih memahami tentang jenis-jenis bukti transaksi serta cara menganalisisnya. Sehingga, siswa mampu melakukan pencatatan akuntansi secara tepat. Hal tersebut dimaksudkan untuk menyesuaikan dengan kebutuhan kompetensi lulusan siswa SMK yang dipersiapkan untuk siap terjun ke dunia kerja.

Terdapat beberapa penelitian sejenis yang pernah dilakukan sebelumnya. Diantaranya adalah penelitian yang dilakukan oleh Amelia (2010) yang berjudul "Pengaruh Penggunaan Media Modul Terhadap Motivasi Belajar dan Implikasinya Terhadap Prestasi Belajar Siswa pada Mata Diklat Komputer Akuntansi”. Berdasarkan hasil penelitian dapat diketahui bahwa dengan adanya penggunaan media modul yang sesuai dapat meningkatkan motivasi belajar siswa. Selain itu juga ada penelitian yang dilakukan oleh Subandrio (2012) dengan judul "Efektifitas Penggunaan Modul dalam Meningkatkan Hasil Belajar Siswa Pada Mata Pelajaran Menggambar Teknik di SMK Negeri 12 Bandung". Hasil penelitian menunjukkan bahwa pembelajaran dengan modul terbukti dapat meningkatkan hasil belajar siswa. Selain itu, modul juga dapat membantu siswa untuk mencapai penguasaan materi pelajaran.

\section{METODE}

Penelitian ini menggunakan model pengembangan Borg dan Gall. Menurut Borg dan Gall (1989) dalam Sukmadinata (2010: 169) ada sepuluh langkah dalam penelitian dan pengembangan, yaitu: Penelitian dan pengumpulan data (research and information collecting), Perencanaan (planning), Pengembangan draf produk (develop premilinary form of product), Uji coba lapangan awal (premilinary field testing), Merevisi hasil uji coba (main product revision), Uji coba lapangan (main field testing), Penyempurnaan produk hasil uji lapangan (operasional product revision), Uji pelaksanaan lapangan 
(operasional field testing), Penyempurnaan produk akhir (final product revision), Diseminasi dan implementasi (dissemination and implementation).

Data yang diambil berupa data kuantitatif dan kualitatif. Instrumen pengumpulan data yang digunakan dalam penelitian ini adalah angket tertutup. Angket tertutup digunakan dalam mengumpulkan data kuantitatif tentang penilaian ahli pengembangan bahan ajar, ahli materi dan pengguna terhadap modul yang dikembangkan. Setelah data terkumpul dari hasil pengumpulan data, selanjutnya data tersebut dianalisis. Data kuantitatif yang diperoleh kemudian diubah ke dalam bentuk presentase untuk diinterpretasikan menjadi data kualitatif.

\section{HASIL DAN PEMBAHASAN}

Pengembangan modul Komputer Akuntansi dengan Pendekatan Bukti Transaksi ini menggunakan model Borg dan Gall (1989) yang telah dimodifikasi. Tahapan yang dilakukan meliputi analisis kebutuhan, pengembangan modul, uji kelayakan modul oleh validator, revisi modul pertama, uji coba lapangan kepada pengguna terbatas, revisi modul kedua yang kemudian menjadi produk akhir. Analisis kebutuhan dilakukan untuk menggali informasi awal yang diperlukan untuk mengatasi masalah pembelajaran. Dengan demikian, modul yang dikembangkan sesuai dengan kebutuhan sekolah dan siswa. Analisis kebutuhan telah dilaksanakan pada 11 Maret 2013 melalui observasi lapangan. Hasil observasi dilapangan menunjukkan bahwa penyampaian materi pembelajaran komputer akuntansi masih didominasi dengan metode ceramah. Meskipun setelah mendapatkan penjelasan dari guru, siswa melakukan praktik dengan komputer, namun hal tersebut kurang efektif karena keterbatasan komputer yang dimiliki sekolah untuk kegiatan pembelajaran. Saat pelaksanaan pembelajaran, satu unit komputer digunakan secara bersamaan oleh 2-3 siswa. Selain itu, bahan ajar yang digunakan dalam kegiatan pembelajaran berupa modul yang hanya berisi soal-soal yang dikerjakan oleh siswa. Sehingga, penyerapan materi oleh siswa kurang optimal.

Berdasarkan wawancara dengan guru mata pelajaran komputer akuntansi diketahui bahwa modul hanya digunakan untuk mengevaluasi keterampilan siswa dalam mengerjakan siklus akuntansi dengan menggunakan program MYOB. Materi pembelajaran disampaikan melalui penjelasan guru dengan bantuan media lainnya, seperti powerpoint. Sedangkan wawancara dengan siswa menghasilkan kesimpulan 
bahwa modul yang digunakan dalam pembelajaran belum mampu mengatasi kesulitan belajar siswa, karena tidak berisi penjelasan langkah-langkah dalam mengerjakan siklus akuntansi dengan program MYOB. Hal tersebut disebabkan oleh kurangnya keterampilan siswa dalam mengoperasikan program komputer akuntansi. Selain itu, siswa di SMK Widya Dharma Turen juga masih kurang menguasai teknik analisis bukti transaksi. Bahkan sebagian siswa ada yang mengalami kesulitan dalam membedakan macam-macam bukti transaksi.

Berdasarkan hasil analisis kebutuhan yang telah dilaksanakan, maka peneliti mengembangkan modul komputer akuntansi dengan pendekatan bukti transaksi. Modul dikembangkan sesuai dengan silabus kelas XII Akuntansi. Komponen pada cover meliputi judul, program keahlian, kelas, dan label identitas siswa. Gambar 4.1 merupakan tampilan cover modul.

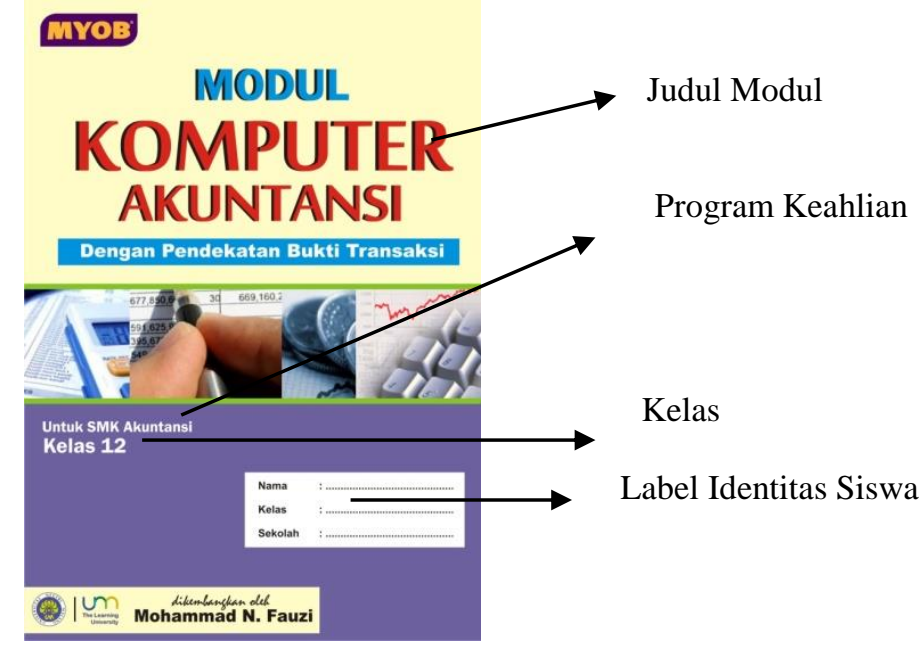

\section{Gambar 4.1 Cover Modul Komputer Akuntansi}

Kata pengantar dibuat untuk mengantarkan atau memperkenalkan pembaca akan isi Modul Komputer Akuntansi dengan Pendekatan Bukti Transaksi. Berikut ini merupakan tampilan kata pengantar pada modul.

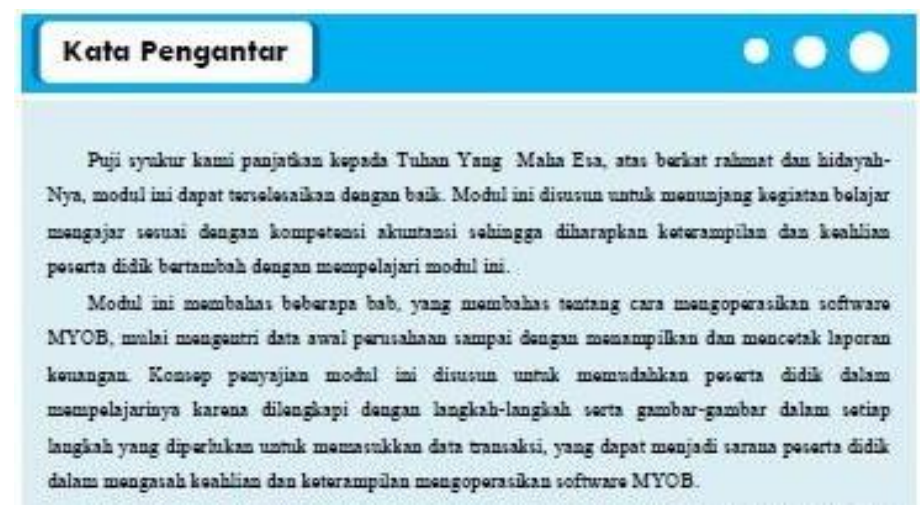


Daftar isi memuat secara rinci isi keseluruhan modul beserta letak nomor halamannya, mulai dari halaman judul sampai dengan soa-soal. Gambar 4.3 berikut ini menunjukkan tampilan Daftar Isi pada modul.

Daftar Isi
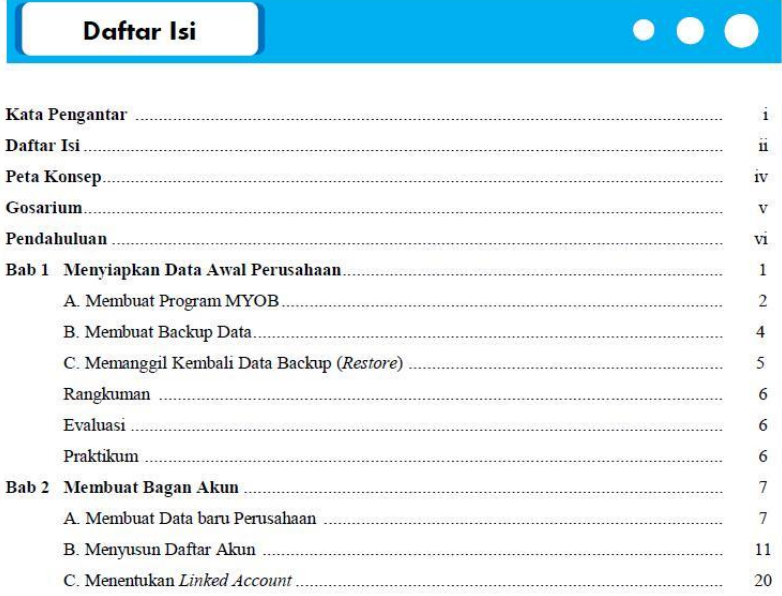

Gambar 4.3 Daftar Isi Modul

Peta konsep berisi tahapan pemrosesan data akuntansi dengan program MYOB, seperti gambar 4.4 berikut ini.

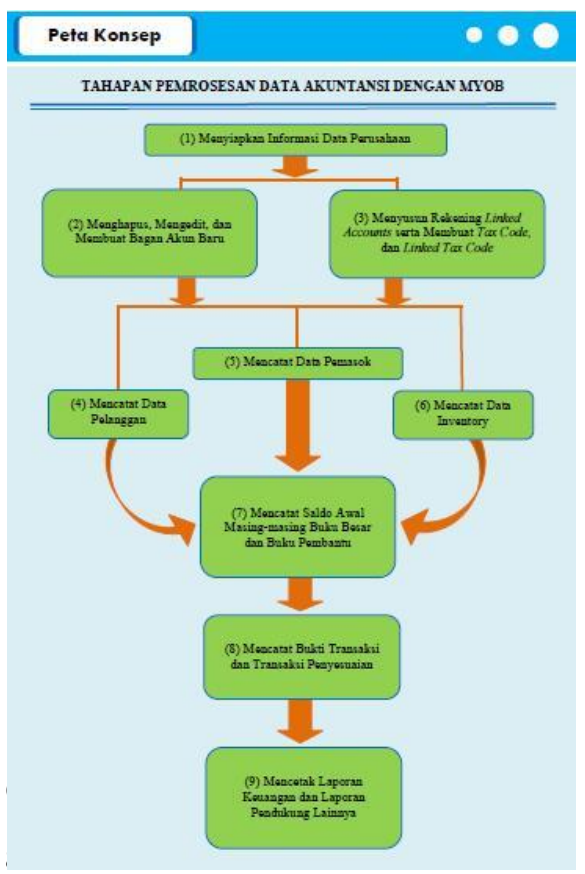


Glosarium memuat penjelasan istilah-istilah yang disusun urut abjad. Tampilan glosarium pada modul seperti gambar 4.5 berikut ini.

\begin{tabular}{|c|c|}
\hline Glosarium & 000 \\
\hline Backup data & $\begin{array}{l}\text { kegiatan menyimpan file data dalam bentuk ZIP dan meletakkannya } \\
\text { di folder Backup. }\end{array}$ \\
\hline Card File (Card List) & $\begin{array}{l}\text { kumpulan kartu dengan pengelompokan sebagai Cistomer, Supplier. } \\
\text { Employee atau Personal. }\end{array}$ \\
\hline Detail & akun yang digunakan sebagai pos penanpumg suatu transaksi. \\
\hline Header & akun yang digunakan sebagan total dari suatu kelompok akun. \\
\hline Jurmal penyesuaian & $\begin{array}{l}\text { berfungsi untuk mengubah sedemikian rupa milai akun sehingega } \\
\text { neraca saldo memperthatkan saldo sebenarnya dari harta, utang. } \\
\text { pendapatan dan beban. }\end{array}$ \\
\hline Laporan Arus Kas & $\begin{array}{l}\text { laporan ketangan yang meranghum selunuh informasi arus kas } \\
\text { masuk (penerimaan-penerimaan) dan arus kas keluar (pembayaran- } \\
\text { pembayaran) pada periode tertentu. }\end{array}$ \\
\hline Laporan LabaRugi & $\begin{array}{l}\text { laporan yang menyajikan pendapatan dan beban yang dihasilkan } \\
\text { selama suatu periode tertentu. }\end{array}$ \\
\hline мүов & $\begin{array}{l}\text { kepanjangan dari Mind Your Own Bussiness, yang berarti bagaimna } \\
\text { cara kita untuk mengelolat transaksi keuangan kita sendiri. }\end{array}$ \\
\hline Neraca & $\begin{array}{l}\text { laporan kevangan yang melaporkan asset, kewajiban, dan ekutas } \\
\text { permlik pada tangeal tertentu. }\end{array}$ \\
\hline
\end{tabular}

Pendahuluan berisi deskripsi modul, prasyarat, petunjuk penggunaan modul, tujuan akhir, kompetensi, dan cek kemampuan. Tampilan pendahuluan modul dapat dilihat pada gambar 4.6 berikut ini.

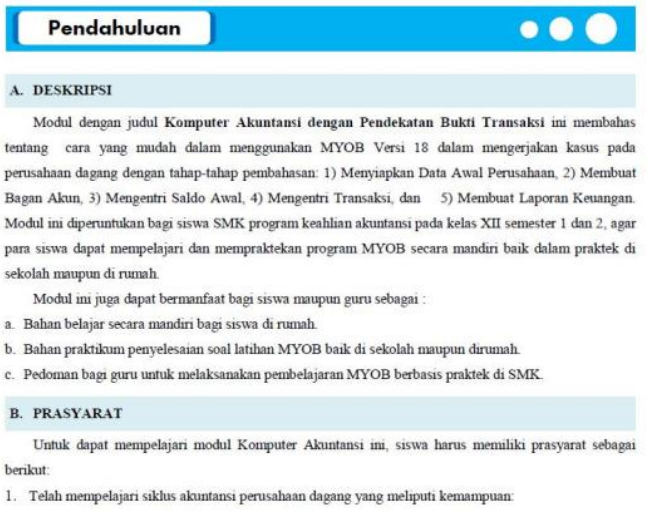

\section{Gambar 4.6 Pendahuluan Modul}

Materi pembelajaran berisi uraian materi komputer akuntansi yang berisi 5 bab. Bab 1 berisi materi Kompetensi Dasar (KD) 1 yaitu menyiapkan data awal perusahaan. Bab 1 juga berisi materi KD 7, yaitu membuat backup file. Materi tersebut dimasukkan pada Bab 1 karena saling berkaitan dan tidak terlalu banyak. Bab 2 berisi materi KD 2 yaitu membuat bagan akun. Materi KD 3 dan 4 dijadikan 1 pada Bab 3 yaitu mengentri saldo awal, karena materinya saling berkaitan. Bab 4 berisi materi KD 5, yaitu mengentri transaksi. Sedangkan Bab 5 berisi KD 6, yaitu membuat laporan keuangan. 
Pada bab 4, yaitu materi tentang mengentri transaksi, disajikan dengan pendektan bukti transaksi. Tampilan materi pembelajaran seperti gambar 4.7 berikut ini.
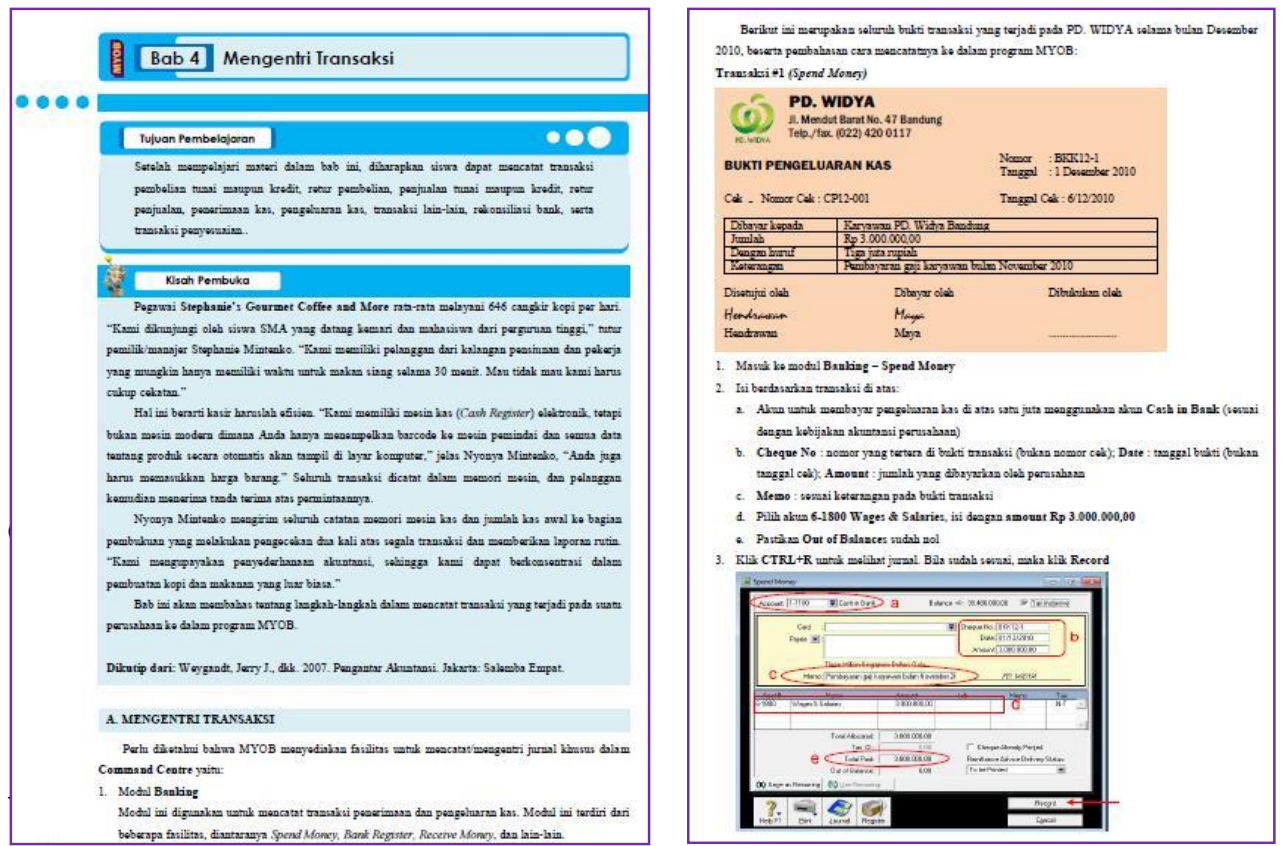

Rangkuman berisi ringkasan materi yang telah dibahas pada materi pembelajaran. Tampilan disajikan per bab. Tampilan rangkuman adalah sebagai berikut.

Rangkuman

- MYOB (Mind Your Own Bussiness) Accounting adalah sebuah program aplikasi akuntansi yang digunakan untuk mengotomatisasi pembukuan secara lengkap, cepat dan akurat.

- Cara membuka program MYOB adalah klik double atau tekan Enter pada icon MYOB yang ada di dekstop.

- Backup data adalah kegiatan menyimpan file data dalam bentuk ZIP dan meletakkannya di folder backup.

- Restore adalah kegiatan memanggil kembali data yang tersimpan dalam bentuk ZIP yang merupakan hasil backup

\section{Gambar 4.8 Ragkuman}


Evaluasi berisi soal untuk menguji kemampuan kognitif siswa dengan soal-soal teori. Berikut ini tampilan evaluasi.

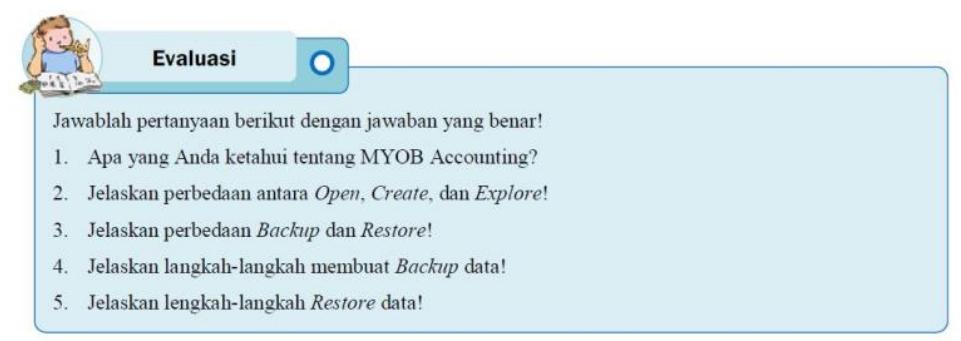

\section{Gambar 4.9 Evaluasi}

Pedoman penilaian berisi cara untuk menilai jawaban peserta didik. Berikut tampilan pedoman penilaian.

Pedoman Penilaian Evaluasi

- Nilai $=$ Jumlah jawaban yang benar $\mathrm{x} 20$

- Nilai maksimal adalah 100

- Anda dinyatakan TUNTAS jika mendapatkan nilai $\geq 77$

\section{Gambar 4.10 Pedoman Penilaian}

Soal praktik berisi soal untuk menguji kemampuan psikomotorik siswa dengan soal praktik secara keseluruhan. Soal praktik disajikan dengan pendekatan bukti transaksi seperti berikut ini.
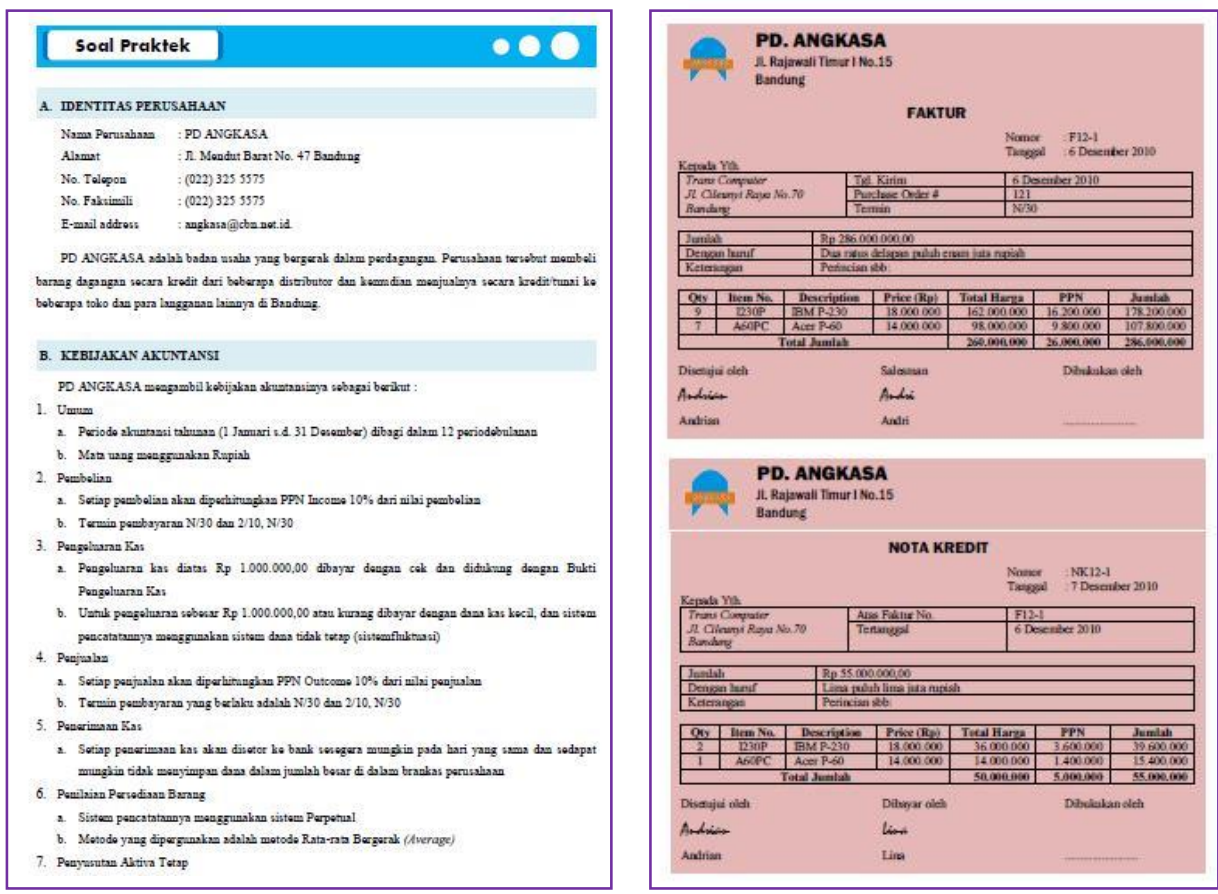
Kunci jawaban berisi jawaban dari soal evaluasi. Dari kunci jawaban, siswa dapat mengevaluasi diri apakah telah mencapai kompetensi yang diajarkan. Tampilan kunci jawaban nampak pada gambar 4.12 berikut ini.

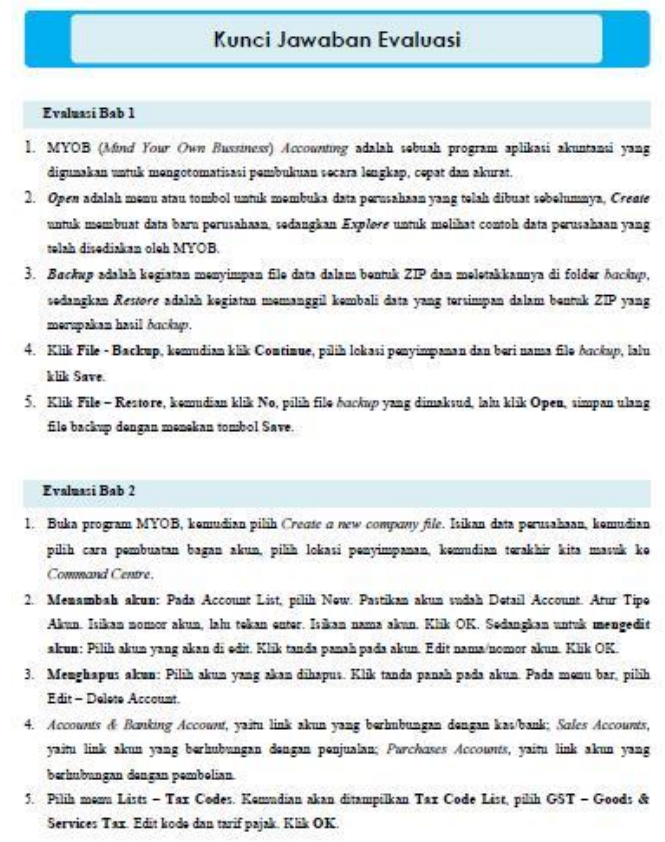

Daftar pustaka merupakan sumber pustaka yang digunakan sebagai acuan dalam penyusunan modul.

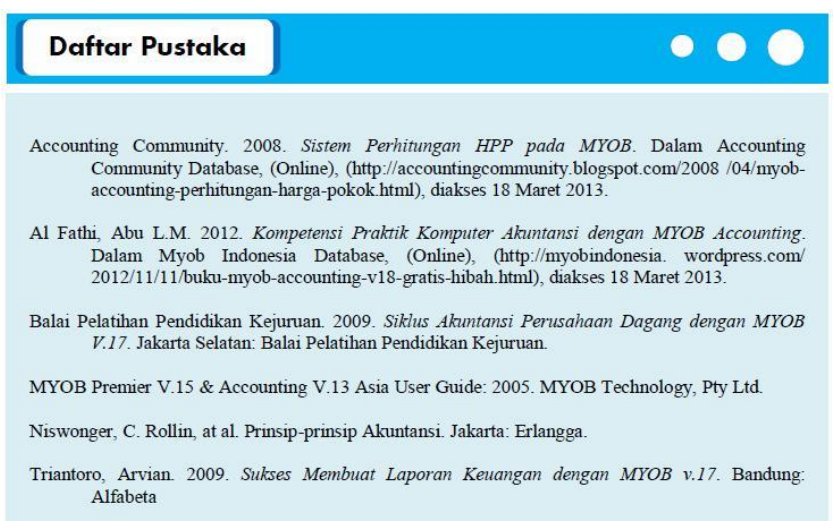

Uji kelayakan modul dilaksanakan dengan melibatkan dua orang validator, yaitu validator materi dan validator mutu modul. Validator materi adalah guru pengajar komputer akuntansi kelas XI dan kelas XII di SMK Widya Dharma Turen, yaitu Ibu Era Indria Aini, S.Pd. Beliau melakukan validasi materi modul pada 8 April 2013. Sedangkan validator mutu modul adalah dosen Pendidikan Akuntansi Fakultas Ekonomi Universitas Negeri Malang, yaitu Ibu Dr. Tri Laksiani, S.E., M.M. Validasi oleh ahli 
pengembangan bahan ajar dilaksanakan pada 11 April 2013. Hasil pengumpulan data berdasarkan angket validasi terdiri dari data kuantitatif dan kualitatif.

Data kuantitatif diperoleh dari skor nilai yang diberikan oleh masing-masing validator terhadap modul. Berikut ini skor yang diberikan oleh ahli materi.

Tabel 4.1 Rangkuman Hasil Validasi Ahli Materi

\begin{tabular}{|c|c|c|c|}
\hline No & Unsur Penilaian & Persentase & Keterangan \\
\hline 1 & Cover & 100 & Valid \\
\hline 2 & Kata Pengantar & 87,50 & Valid \\
\hline 3 & Daftar Isi & 100 & Valid \\
\hline 4 & Glosarium & 91,67 & Valid \\
\hline 5 & Deskripsi & 100 & Valid \\
\hline 6 & Prasyarat & 100 & Valid \\
\hline 7 & Petunjuk Penggunaan Modul & 100 & Valid \\
\hline 8 & Tujuan Akhir & 100 & Valid \\
\hline 9 & Standar Kompetensi dan Kompetensi Dasar & 100 & Valid \\
\hline 10 & Cek Kemampuan & 100 & Valid \\
\hline 11 & Materi & 100 & Valid \\
\hline 12 & Gambar & 100 & Valid \\
\hline 13 & Rangkuman & 100 & Valid \\
\hline 14 & Evaluasi & 100 & Valid \\
\hline 15 & Pedoman Penilaian & 100 & Valid \\
\hline 16 & Kunci Jawaban Evaluasi & 100 & Valid \\
\hline 17 & Soal Praktik & 87,50 & Valid \\
\hline 18 & Daftar Pustaka & 87,50 & Valid \\
\hline & Rata-rata & 97,45 & Valid \\
\hline
\end{tabular}

\section{Sumber: Angket Validasi Ahli Materi}

Berdasarkan tabel 4.1 diketahui bahwa modul dinyatakan valid untuk digunakan dengan persentase sebesar 97,45\%. Sedangkan data kuantitatif dari penilaian validator mutu modul dapat dilihat pada tabel 4.2 berikut ini.

Tabel 4.2 Rangkuman Hasil Validasi Ahli Pengembangan Bahan Ajar

\begin{tabular}{llll}
\hline No & Unsur Penilaian & Persentase & Keterangan \\
\hline 1 & Format & 100 & Valid \\
\hline 2 & Organisasi & 100 & Valid \\
\hline 3 & Daya Tarik & 100 & Valid \\
\hline 4 & Bentuk dan Ukuran Huruf & 100 & Valid \\
\hline
\end{tabular}




\begin{tabular}{llll}
\hline 5 & Ruang/Spasi Kosong & 100 & Valid \\
\hline 6 & Konsistensi & 100 & Valid \\
\hline & Rata-rata & $\mathbf{1 0 0}$ & Valid \\
\hline
\end{tabular}

Sumber: Angket Validasi Mutu Modul

Berdasarkan tabel 4.2 diketahui bahwa ahli pengembangan bahan ajar menyatakan bahwa modul valid untuk digunakan dengan persentase sebesar $100 \%$.

Data kualitatif diperoleh dari kritik dan saran validator. Tabel 4.3 menunjukkan kritik dan saran dari validator materi dan validator mutu modul.

Tabel 4.3 Kritik dan Saran Validator

\begin{tabular}{|c|c|}
\hline Validator & Kritik dan Saran \\
\hline \multirow[t]{3}{*}{ 1. Materi } & $\begin{array}{l}\text { 1. Penggunaan huruf dalam modul agak diperkecil dan jarak baris } \\
\text { diatur sedemikian rupa sehingga tidak terkesan padat }\end{array}$ \\
\hline & $\begin{array}{l}\text { 2. Soal evaluasi hendaknya tidak hanya berisi soal teori saja tetapi juga } \\
\text { soal praktik karena disamping dinilai secara kognitif siswa juga } \\
\text { harus dinilai secara skillnya. }\end{array}$ \\
\hline & $\begin{array}{l}\text { 3. Glosarium bendanya memuat semua istilah-istilah yang mungkin } \\
\text { siswa belum mengenal istilah yang bersangkutan. }\end{array}$ \\
\hline
\end{tabular}

2. Mutu Modul Sudah sesuai

\section{Sumber: Angket Validasi Ahli Materi dan Mutu Modul}

Data kualitatif hasil validasi ahli materi dan pengembangan bahan ajar tersebut dijadikan dasar untuk revisi modul ke-1. Validator mutu modul telah menyatakan modul valid dan layak 100\% untuk digunakan dan tidak memberikan kritik dan saran, sehingga peneliti merevisi modul berdasarkan kritik dan saran validator materi saja. Menurut validator materi, modul telah valid dan layak untuk digunakan, tetapi ada beberapa bagian yang harus direvisi sesuai dengan kritik dan saran yang telah diberikan pada saat validasi. Berikut ini revisi yang peneliti lakukan agar kualitas modul lebih baik lagi. 


\section{Penggunaan Huruf Diperkecil dan Jarak Baris Diatur}

Modul awalnya disusun dengan menggunakan jenis font Times New Roman dengan ukuran huruf yang standar, yaitu 12 pt dan jarak baris (spasi) yang digunakan adalah 1,15. Sesuai saran validator, maka ukuran huruf direvisi menjadi 11 pt dan jarak baris menjadi 1,5 .

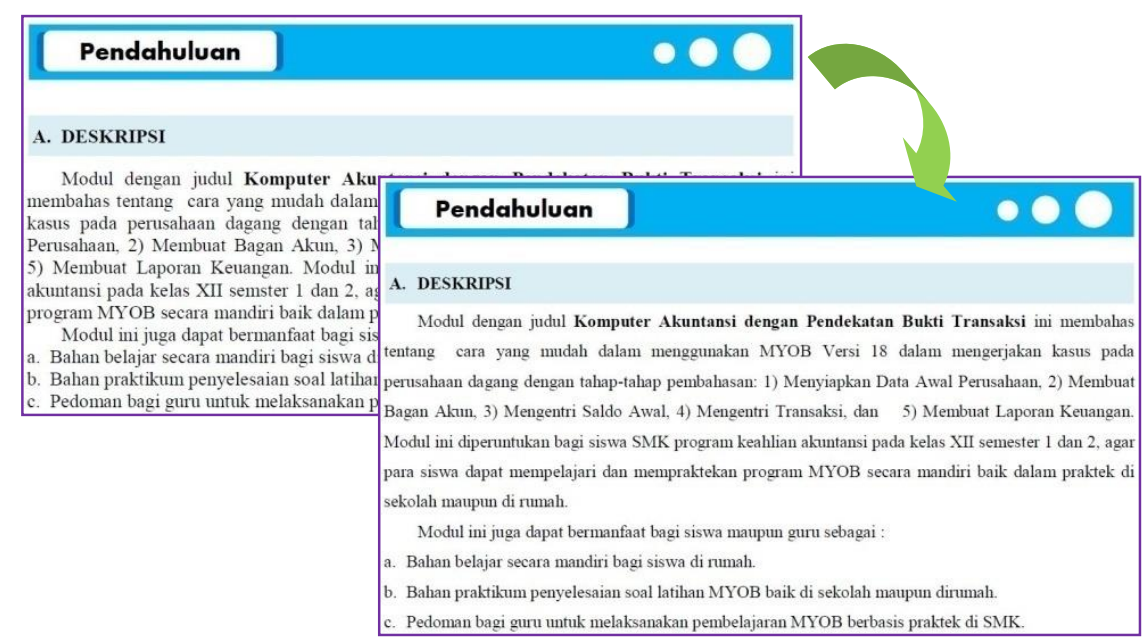

\section{Gambar 4.14 Perubahan Ukuran Huruf dan Jarak Baris}

\section{Soal Evaluasi Hendaknya Tidak Hanya Teori tetapi juga Soal Praktik}

Soal-soal pada modul terdiri dari dua jenis, yaitu soal evaluasi yang berisi soal teori yang ada pada setiap bab dan juga soal praktik yang ada pada bagian akhir untuk mengevaluasi kompetensi siswa secara keseluruhan. Berdasarkan kritik dan saran dari validator materi, maka peneliti menambahkan soal praktikum pada setiap bab.
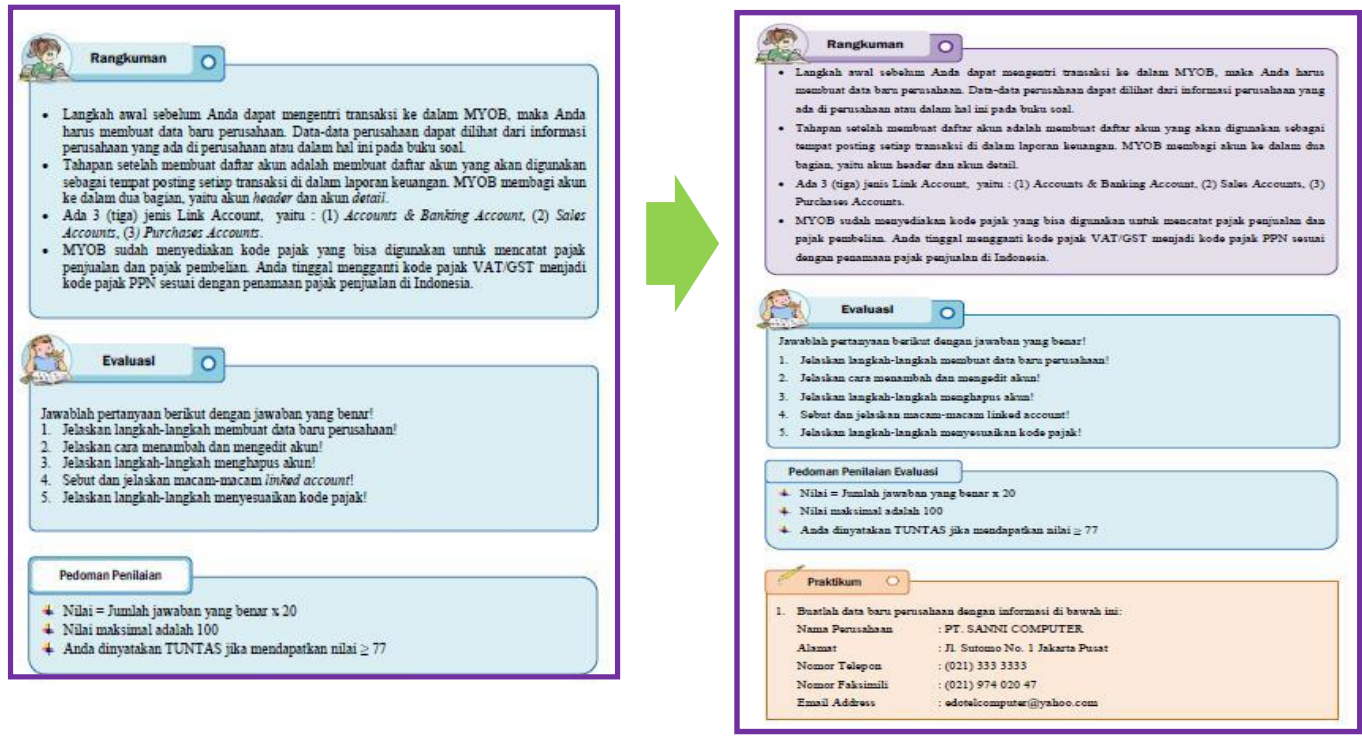


\section{Glosarium Hendaknya Juga Memuat Istilah yang Siswa Belum Mengenal}

Berdasarkan kritik dan saran dari validator materi, maka peneliti menambahkan beberapa istilah akuntansi yang ada pada modul komputer akuntansi yang siswa belum banyak mengenal. Istilah-itilah yang ditambahkan meliputi Neraca Saldo, Jurnal Penyesuaian, Laporan Laba Rugi, Neraca, dan Laporan Arus Kas.

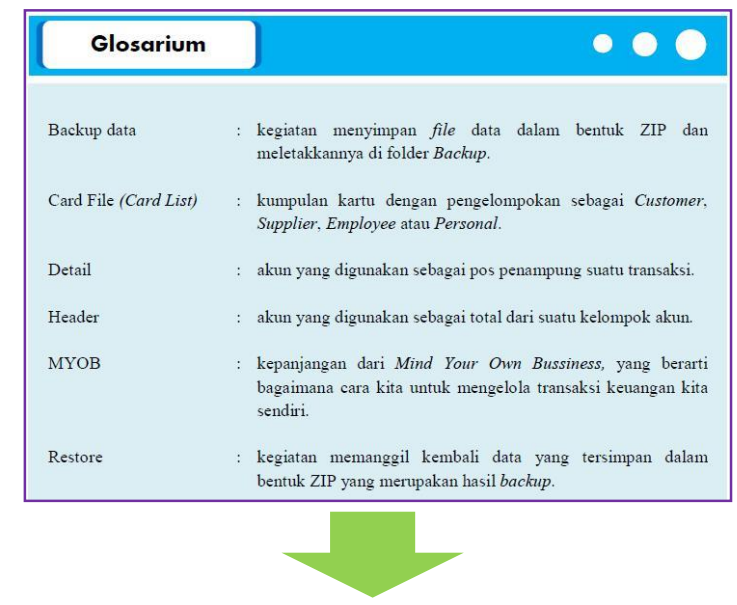

\begin{tabular}{|c|c|}
\hline Glosarium & 000 \\
\hline Backup data & $\begin{array}{l}\text { : kegiatan menyimpan file data dalam bentuk ZIP dan meletakkannya } \\
\text { di folder Bachup. }\end{array}$ \\
\hline Card File (Card List) & $\begin{array}{l}\text { : kumpulan kartu dengan pengelompokan sebagai Customer, Supplier, } \\
\text { Employee atau Personal. }\end{array}$ \\
\hline Detail & akun yang digunakan sebagai pos penampung suatu transaksi. \\
\hline Header & alun yang digunakan sebagai total dari suatu kelompok akun. \\
\hline Jumal penyesuaian & $\begin{array}{l}\text { : berfungsi untuk mengubah sedemikian rupa nilai alun sehingga } \\
\text { neraca saldo memperlihatkan saldo sebenarnya dari harta, utang, } \\
\text { pendapatan dan beban }\end{array}$ \\
\hline Laporan Arus Kas & $\begin{array}{l}\text { laporan keuangan yang merangkum seluruh informasi arus kas } \\
\text { masulk (penerimaan-penerimaan) dan arus kas keluar (pembayaran- } \\
\text { pembayaran) pada periode tertentu. }\end{array}$ \\
\hline Laporan Laba/Rugi & $\begin{array}{l}\text { : laporan yang menyajikan pendapatan dan beban yang dihasilkan } \\
\text { selama suatu periode tertentu. }\end{array}$ \\
\hline МҮOВ & $\begin{array}{l}\text { : kepanjangan dari Mind Your Orn Bussiness, yang berarti bagaimana } \\
\text { cara kita untuk mengelola transaksi keuangan kita sendiri. }\end{array}$ \\
\hline Neraca & $\begin{array}{l}\text { laporan keuangan yang melaporkan asset, kewajiban, dan ekuitas } \\
\text { pemilik pada tanggal tertentu. }\end{array}$ \\
\hline Neraca Lajur & $\begin{array}{l}\text { media pencatatan neraca saldo, jumal penyesuaian, laporan laba rugi, } \\
\text { dan neraca yang disusun secara logis untuk mempermudah } \\
\text { penyusunan laporan keuangan. }\end{array}$ \\
\hline Neraca saldo & $\begin{array}{l}\text { : daftar yang memuat saldo dari akun-akun yang terdapat dalam bulu } \\
\text { besar. }\end{array}$ \\
\hline Restore & $\begin{array}{l}\text { : kegiatan memanggil kembali data yang tersimpan dalam bentuk ZIP } \\
\text { yang merupakan hasil backup. }\end{array}$ \\
\hline
\end{tabular}

Uji coba lapangan terbatas dilaksanakan untuk mengetahui kelayakan dan kemenarikan modul yang dikembangkan jika dilihat dari perspektif siswa. Uji ini dilaksanakan pada sampel sebanyak 33 siswa kelas XII SMK Widya Dharma Turen. Uji coba modul dilaksanakan pada Jumat, 12 April 2013. 
Berdasarkan uji coba lapangan, diperoleh hasil berupa data kuantitatif dan data kualitatif. Data kuantitatif berupa skor penilaian yang diberikan siswa terhadap modul yang dikembangkan dengan rangkuman sebagai berikut.

\section{Tabel 4.4 Rangkuman Hasil Penilaian Pengguna}

\begin{tabular}{|c|c|c|c|}
\hline No & Unsur Penilaian & $\%$ & Keterangan \\
\hline 1 & Tampilan cover modul menarik & 83,33 & Valid \\
\hline 2 & $\begin{array}{l}\text { Penempatan gambar, komposisi warna, dan } \\
\text { penggunaan huruf pada cover jelas dan tepat }\end{array}$ & 86,36 & Valid \\
\hline 3 & $\begin{array}{l}\text { Peta konsep modul mudah dipahami dan } \\
\text { menarik }\end{array}$ & 93,94 & Valid \\
\hline 4 & Materi dalam modul mudah dipahami & 91,67 & Valid \\
\hline 5 & $\begin{array}{l}\text { Modul ini membuat saya lebih mengerti } \\
\text { tentang MYOB }\end{array}$ & 93,94 & Valid \\
\hline 6 & $\begin{array}{l}\text { Modul ini membuat saya lebih menguasai } \\
\text { cara mengoperasikan MYOB }\end{array}$ & 86,36 & Valid \\
\hline 7 & $\begin{array}{l}\text { Modul ini membuat saya lebih memahami } \\
\text { tentang macam-macam bukti transaksi }\end{array}$ & 93,94 & Valid \\
\hline 8 & $\begin{array}{l}\text { Modul ini membuat saya lebih memahami } \\
\text { cara menganalisis dan mencatat bukti } \\
\text { transaksi ke dalam MYOB }\end{array}$ & 93,94 & Valid \\
\hline 9 & $\begin{array}{l}\text { Soal evaluasi dalam modul jelas dan mudah } \\
\text { dipahami }\end{array}$ & 81,82 & Valid \\
\hline 10 & $\begin{array}{l}\text { Susunan materi, gambar, dan ilustrasi mudah } \\
\text { dipahami dan menarik }\end{array}$ & 96,97 & Valid \\
\hline 11 & $\begin{array}{l}\text { Bahasa yang digunakan dalam modul jelas } \\
\text { dan mudah dipahami }\end{array}$ & 92,42 & Valid \\
\hline 12 & $\begin{array}{l}\text { Modul ini secara keseluruhan menarik dan } \\
\text { mudah dipahami }\end{array}$ & 86,36 & Valid \\
\hline 13 & $\begin{array}{l}\text { Modul ini membuat saya lebih termotivasi } \\
\text { untuk belajar akuntansi, khususnya MYOB }\end{array}$ & 82,58 & Valid \\
\hline & Rata-Rata & $\mathbf{8 9 , 5 1}$ & Valid \\
\hline
\end{tabular}

Sumber: Angket Uji Coba Lapangan Terbatas

Berdasarkan tabel 4.4 diketahui bahwa pengguna menyatakan modul valid dan layak digunakan dengan persentase $89,51 \%$. Dengan demikian, secara keseluruhan menurut perspektif pengguna, modul telah menarik dan mudah dipahami. Selain itu, modul juga dapat memotivasi siswa untuk belajar akuntansi, khususnya MYOB. 
Di sisi lain, berdasarkan data kualitatif diperoleh beberapa kritik dan saran dari pengguna terhadap modul. Data tersebut akan digunakan untuk melakukan revisi ke-2 sebelum menjadi produk akhir. Berikut ini rangkuman dari kritik dan saran pengguna terhadap modul yang dikembangkan.

Tabel 4.5 Rangkuman Kritik dan Saran Pengguna

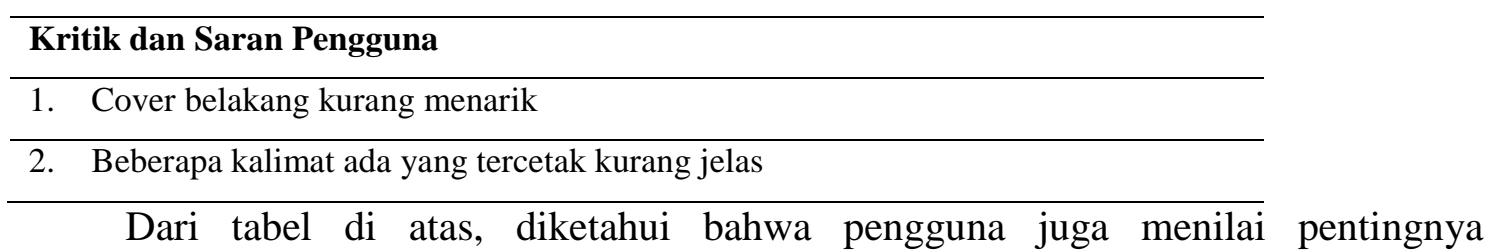
memperhatikan tampilan cover belakang agar kemasan modul lebih menarik lagi. Selain itu, kualitas percetakan juga harus diperhatikan.

Pada uji coba lapangan terbatas dapat diketahui bahwa siswa cukup antusias dalam menggunakan modul sebagai panduan dalam mengoperasikan program komputer akuntansi. Materi disajikan secara lengkap dan sistematis dengan didukung tampilan pada program (screenshot), sehingga lebih mudah dipahami. Penjelasan materi lebih banyak menggunakan contoh pemecahan soal praktik untuk lebih memudahkan siswa dalam memahami langkah-langkah mengerjakan siklus akuntansi dengan program MYOB. Dengan adanya modul komputer akuntansi, siswa lebih bersemangat dalam mempelajari materi. Hal tersebut didukung dengan hasil angket yang menunjukkan bahwa aspek kemudahan dalam memahami materi mendapatkan persentase sebesar 91,67\% dan kemudahan memahami macam-macam bukti transaksi serta cara menganalisisnya mendapatkan persentase sebesar 93,94\%. Hasil tersebut menunjukkan bahwa penyajian materi dalam modul valid dan layak untuk digunakan.

Penyajian evaluasi dalam modul dinyatakan valid dan layak digunakan. Hal ini didukung dengan hasil angket yang menyatakan bahwa kejelasan dan kemudahan dalam memahami soal dalam modul mendapatkan persentase sebesar 81,82\%. Selain itu, evaluasi ini juga disertai dengan kunci jawaban agar siswa dapat belajar secara mandiri.

Pengemasan modul komputer akuntansi, mulai dari tampilan cover, penempatan gambar, ilustrasi, maupun secara keseluruhan sudah menarik. Hal tersebut dibuktikan dengan adanya hasil angket yang menunjukkan bahwa kemenarikan tampilan cover mendapat persentase sebesar $83,33 \%$, kemenarikan penyajian peta konsep mendapat presentase 93,94\%, serta kemenarikan penyusunan materi, gambar, dan ilustrasi mendapat persentase sebesar $96,97 \%$. Namun siswa sebagai pengguna juga memberikan 
saran bahwa tampilan cover pada bagian belakang modul sebaiknya dikemas lebih menarik lagi. Sehingga pada aspek kemenarikan tampilan cover perlu direvisi. Selain itu, siswa juga menemukan bahwa terdapat beberapa kalimat yang tercetak kurang jelas. Hal tersebut juga menjadi masukan untuk memperbaiki kualitas cetak pada modul.

Secara keseluruhan modul dinyatakan menarik dan mudah dipahami dengan persentase sebesar $86,36 \%$. Selain itu, modul ini membuat pengguna lebih termotivasi untuk belajar akuntansi, khususnya MYOB yang dinyatakan dengan persentase sebesar 82,58\%. Dengan demikian, menurut perspektif pengguna, modul ini secara umum menarik, mudah dipahami, dan dapat memotivasi siswa untuk mempelajari komputer akuntansi.

Tabel 4.6 Analisis Keseluruhan Validasi

\begin{tabular}{llll}
\hline No & Aspek yang Dinilai & Persentase (\%) & Keterangan \\
\hline 1 & Rata-rata validasi ahli materi & 97,45 & Valid \\
\hline 2 & Rata-rata validasi ahli mutu modul & 100 & Valid \\
\hline 3 & Rata-rata uji coba lapangan terbatas & 89,51 & Valid \\
\hline & Rata-rata keseluruhan validasi & $\mathbf{9 5 , 6 5}$ & Valid \\
\hline
\end{tabular}

Sumber: Angket Validasi Ahli Materi, Ahli Mutu Modul, dan Uji Coba Terbatas

Berdasarkan Tabel 4.6 analisis keseluruhan validasi diperoleh dari ahli materi dengan nilai rata-rata persentase $97,45 \%$, ahli mutu modul diperoleh nilai rata-rata persentase sebesar $100 \%$ dan uji coba lapangan terbatas diperoleh nilai rata-rata sebesar $89,51 \%$. Sehingga rata-rata persentase keseluruhan sebesar 95,65\% dan dapat disimpulkan bahwa modul komputer akuntansi dengan pendekatan bukti transaksi dinyatakan valid dan layak untuk digunakan dalam proses pembelajaran pada siswa kelas XII di SMK Widya Dharma Turen.

Revisi ke-2 dilakukan apabila setelah diujicobakan masih terdapat ketidakvalidan modul yang dihasilkan berdasarkan penilaian, kritik, dan saran dari pengguna terbatas. Berikut ini merupakan revisi yang dilakukan berdasarkan kritik dan saran pengguna.

\section{Cover Belakang Kurang Menarik}

Sebelumnya cover belakang hanya dibuat dengan satu warna. Berdasarkan kritik dan saran pengguna, cover belakang direvisi dengan kombinasi beberapa warna. Selain itu, peneliti juga menambahkan deskripsi modul dan riwayat penulis pada bagian cover belakang. 

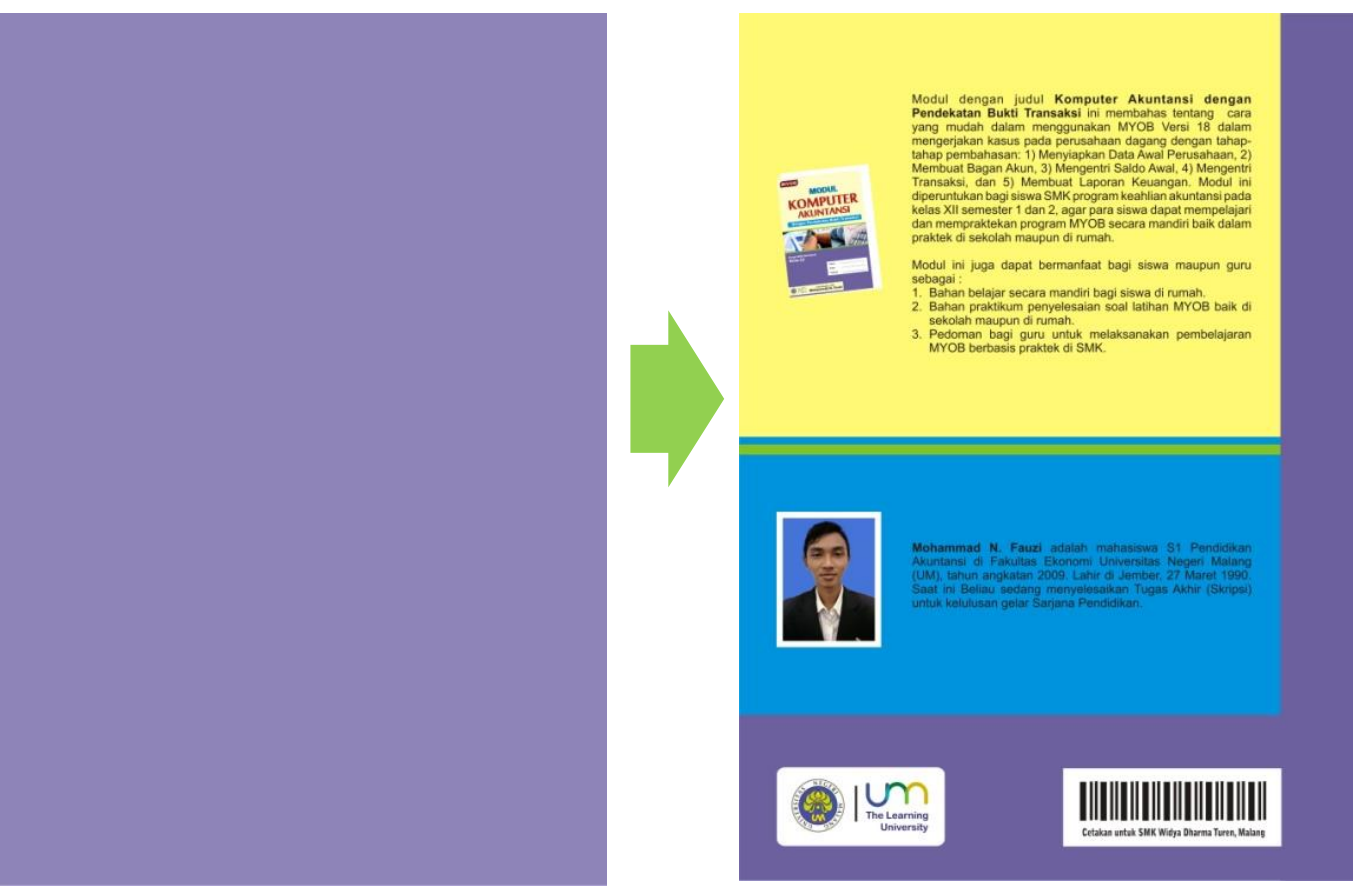

Gambar 4.17 Revisi Cover Belakang Modul

\section{Beberapa Kalimat Ada yang Tercetak Kurang Jelas}

Ketidakjelasan yang dimaksud tersebut disebabkan proses cetak (printing) yang bermasalah, sehingga ada beberapa kata yang tercetak kurang tebal. Perbaikan yang dilakukan adalah dengan memperbaiki kualitas cetak modul.

Berdasarkan analisis data hasil validasi ahli materi, ahli mutu modul, dan uji coba lapangan terbatas dapat disimpulkan bahwa modul komputer akuntansi dengan pendekatan bukti transaksi telah dinyatakan valid dan layak untuk pembelajaran di kelas maupun mandiri. Modul tersebut dapat digunakan untuk pembelajaran pada siswa kelas XII Jurusan Akuntansi SMK Widya Dharma Turen pada semester 1 dan 2. Produk akhir terlampir pada lampiran 14.

\section{SIMPULAN}

Produk akhir hasil pengembangan dalam penelitian ini berupa modul komputer akuntansi dengan pendekatan bukti transaksi. Produk yang dihasilkan digunakan dalam pembelajaran komputer akuntansi pada siswa kelas XII Akuntansi. Produk yang dikembangkan ini telah direvisi dan dinyatakan valid berdasarkan hasil validasi ahli materi, ahli mutu modul, dan uji coba kepada pengguna lapangan terbatas. 
Berdasarkan hasil uji coba lapangan terbatas kepada pengguna, dapat diketahui bahwa modul komputer akuntansi ini layak digunakan dan dapat mengatasi kesulitan siswa dalam mengoperasikan program komputer akuntansi. Secara keseluruhan, pengguna menilai bahwa materi, evaluasi, serta tampilan modul telah disajikan dengan menarik dan mudah dipahami. Dengan adanya modul komputer akuntansi, siswa lebih bersemangat dalam mempelajari materi.

Hasil proses uji coba produk tersebut didukung dengan hasil validasi yang diperoleh dari ahli materi sebesar 97,45\%, ahli mutu modul sebesar 100\%, dan uji coba lapangan terbatas sebesar $89,51 \%$. Sehingga apabila hasil tersebut dihitung secara keseluruhan, diperoleh rata-rata sebesar 95,65\%. Dari hasil analisis tersebut, dapat disimpulkan bahwa bahan ajar berupa modul komputer akuntansi dengan pendekatan bukti transaksi dinyatakan valid dan layak digunakan dalam proses pembelajaran komputer akuntansi di SMK Widya Dharma Turen. Hal tersebut diperkuat dengan pendapat Dikti (2012) bahwa bahan ajar disusun untuk empat tujuan, yaitu (1) membantu siswa dalam mempelajari sesuatu, (2) menyediakan berbagai jenis pilihan bahan ajar, (3) memudahkan guru dalam melaksanakan pembelajaran, dan (4) agar kegiatan pembelajaran menjadi lebih menarik.

\section{DAFTAR RUJUKAN}

Amelia, Nurul Fitriani. 2010. Pengaruh Penggunaan Media Modul Terhadap Motivasi Belajar dan Implikasinya Terhadap Prestasi Belajar Siswa pada Mata Diklat Komputer Akuntansi. Skripsi diterbitkan, (Online), (http://repository.upi.edu), diakses 21 Desember 2012.

Arikunto, Suharsimi. 2010. Prosedur Penelitian: Suatu Pendekatan Praktik. Jakarta: Rineka Cipta.

Departemen Pendidikan Nasional. 2009. Pengembangan Modul SMK. Materi Disajikan pada Pelatihan KTSP 2009. Dalam Risdiana Hidayat database, (Online), (http://www.slideshare.net/Risdiana/teknik-penyusunan-modul-smk), diakses 2 Januari 2012.

Dikti. 2012. Pengembangan Bahan Ajar. Materi Disajikan pada Sosialisasi KTSP. Dalam Dikti database, (Online), (www.dikti.go.id/files/atur/KTSP-SMK), diakses 21 Desember 2012.

Direktorat Pembinaan Sekolah Menengah Kejuruan. 2008. Teknik Penyusunan Modul. Materi disajikan sebagai Bahan Bimbingan Teknis Implementasi KTSP. Dalam 
SMK Negeri 1 Majalengka database, (Online), (http://download.smkn1majalengka.sch.id), diakses 1 Februari 2013.

Indra, Rendra Prima. 2010. Pengelolaan Bukti Transaksi, (Online), (http://primaklaten.blogspot.com/2010/03/bukti-transaksi.html), diakses 11 Februari 2013.

Komalasari, Kokom. 2011. Pembelajaran Kontekstual: Konsep dan Aplikasi. Bandung: PT. Rafika Aditama.

Nasution, S. 2010. Berbagai Pendekatan dalam Proses Belajar dan Mengajar. Jakarta: PT. Bumi Aksara.

Setyosari, P dan Sihkabuden. 2005. Media Pembelajaran. Malang: Elang Mas.

Subandrio. 2012. Efektifitas Penggunaan Modul dalam Meningkatkan Hasil Belajar Siswa Pada Mata Pelajaran Menggambar Teknik di SMK Negeri 12 Bandung. Skripsi diterbitkan, (Online), (http://repository.upi.edu), diakses 21 Desember 2012.

Sudjana, Nana. 1990. Penelitian Hasil Proses Belajar Mengajar. Bandung: PT. Remaja Rosdakarya.

Sugiyono. 2011. Metode Penelitian Pendidikan: Pendekatan Kuantitatif, Kualitatif, dan $R \& D$. Bandung: Alfabeta.

Sukmadinata, Nana S. 2010. Metode Penelitian Pendidikan. Bandung: PT. Remaja Rosdakarya.

Sumarsan, Thomas. 2011. Akuntansi Dasar dan Aplikasi dalam Bisnis. Jakarta: PT. Indeks.

Universitas Negeri Malang. 2010. Pedoman Penulisan Karya Ilmiah. Malang: Universitas Negeri Malang.

Yadiati, Winwin dan Wahyudi, Ilham. 2008. Pengantar Akuntansi. Jakarta: Kencana. 